O.Y. Lozynskyi, A.O. Lozynskyi, Y.S. Paranchuk, R.Y. Paranchuk

\title{
SYNTHESIS AND ANALYSIS OF ARC FURNACE ELECTRICAL MODE CONTROL SYSTEM ON THE BASIS OF THREE-DIMENSIONAL PHASE CURRENTS VECTOR DISTRIBUTION
}

Goal. The purpose of the article is to create the method for the operative synthesis of an arc steel-melting furnace (ASF) electric mode (EM) control signal on the basis of a three-dimensional arc currents vector, which takes into account the stochastic nature of the processes in the melting space and power circuit and has low sensitivity to the control object parameters changes, as well as development of the control system structure for its implementation. Method. The basis of the created control method is formed on the statistical theory of dynamical systems, as well as the provisions of the statistical theory of optimal control based on the Fokker-Planck-Kolmogorov equation, which enables to synthesize operational control by the criterion of approaching the regulated coordinate distribution density to the $\delta$-function, that is to minimize the dispersion of the three-dimensional furnace phases arc currents vector. Results. The system of equations for operational real-time calculation of control influences of the thyristor switch of phase inductors, included in the power supply circuits of three-phase arcs, and the structural scheme of the adaptive contour for the formation of three-dimensional phase currents vector dispersion for the implementation of adaptive optimal control were obtained. Scientific novelty. For the first time, based on the Fokker-Planck-Kolmogorov equation, we obtain a system of equations representing a mathematical model of a stochastic adaptive optimal control of the arc furnace electric mode by the criterion of a minimum dispersion of three-dimensional phase (arcs) currents vector, which enables, in comparison with known methods, to increase dynamic precision of the arc currents stabilization at the level set by the criteria of energy efficiency and electromagnetic compatibility values. Practical value. The use of the proposed adaptive optimal control model and structural system scheme for its implementation allows, in comparison with the serial arc power regulators, to improve the dynamic accuracy of the arc current currents stabilization at the level of given optimal settings and, based on this, to improve the energy efficiency and electromagnetic compatibility indices of the arc furnace and power supply network. References 18 , figures 5.

Key words: arc furnace, electric mode, three-dimensional vector of phase currents, stochastic control, dispersion, optimization, adaptation, arc current control circuit.

Мета. Метою статті с створення методу оперативного синтезу сигналу керування електричним режимом (ЕР) дугової сталеплавильної печі (ДСП) на основі тривимірного вектора струмів фаз, щчо враховує стохастичну природу процесів у плавильному просторі, силовому електричному колі печі, має низьку чутливість до зміни параметрів об'єкта керування та розроблення структури системи керування для його реалізації. Методика. В основу створеного методу керування покладено положення статистичної теорї динамічних систем, а такожс положення статистичної теорії оптимального керування на основі рівняння Фоккера-Планка-Колмогорова, щчо дає змогу синтезувати оперативне керування за критерісм наближенням густини розподілу регульованої координати до $\delta$ функції, тобто мінімізувати дисперсію тривимірного вектора струмів фаз (дуг) дугової печі. Результати. Отримано систему рівнянь для оперативного в режимі оп-line розрахунку керуючих впливів тиристорного комутатора фазних дроселів, що включені у силове коло живлення трифазних дуг, та структурну схему адаптивного контура формування дисперсї̈ тривимірного вектора струмів дуг дугової печі для реалізації адаптивного оптимального керування. Наукова новизна. Виерие на основі рівняння Фоккера-Планка-Колмогорова отримано систему рівнянь, цо подають математичну модель стохастичного адаптивного оптимального керування електричним режсиом дугової сталеплавильної печі за критерієм мінімуму дисперсії тривимірного вектора струмів дуг, щчо дає змогу у порівнянні 3 відомими методами підвищити динамічну точність стабілізацї струмів дуг на рівні заданих за критеріями енергоефективності та електромагнітної сумісності значень. Практична цінність. Реалізація запропонованої моделі адаптивного оптимального керування та структурної схеми системи для ї̈ реалізації дасть змогу у порівнянні 3 серійними регуляторами потужності дуг поліпшити динамічну точність стабілізації струмів дуг на рівні заданих оптимальних уставок і на основі цього комплексно поліпшити показники енергоефективності та електромагнітної сумісності режимів дугової печі та електромережі. Бібл. 18, рис. 5.

Ключові слова: дугова сталеплавильна піч, електричний режим, тривимірний вектор струмів фаз, стохастичне керування, дисперсія, оптимізація, адаптація, контур регулювання струмів дуг.

Цель. Целью статьи является создание метода оперативного синтеза сигнала управления электрическим режимом (ЕР) дуговой сталеплавильной печи (ДСП) на основе трехмерного вектора токов фаз, который учитывает стохастическую природу процессов в плавильном пространстве, силовой электрической цепи печи, имеет низкую чувствительность к изменению параметров объекта управления и разработка структуры системы управления для его реализации. Методика. В основе созданного метода управления использованы положения статистической теории динамических систем, а также положение статистической теории оптимального управления на основе уравнения Фоккера-Планка-Колмогорова, что позволяет синтезировать оперативное управление по критерию приближения плотности распределения регулируемой координаты к $\delta$-функции, то есть минимизировать дисперсию трехмерного вектора токов дуг дуговой печи. Результаты. Получена система уравнений для оперативного в режиме оп-liпе расчета управляющих воздействий тиристорного коммутатора фазных дросселей, включенных в силовую цепь питания трехфазных дуг, и структурную схему адаптивного контура формирования дисперсии трехмерного вектора токов фаз дуговой печи для реализации адаптивного оптимального управления. Научная новизна. Впервые на основе уравнения Фоккера-Планка-Колмогорова получена система уравнений, представляющих математическую модель стохастического адаптивного оптимального управления электрическим режсимом дуговой сталеплавильной печи по

(C) O.Y. Lozynskyi, A.O. Lozynskyi, Y.S. Paranchuk, R.Y. Paranchuk 
критерию минимума дисперсии трехмерного вектора токов дуд, что позволяет по сравнению с известными методами повысить динамическую точность стабилизации токов дуг на уровне заданных по критериям энергоэффективности и электромагнитной совместимости значений. Практическая ценность. Реализация предложенной модели адаптивного оптимального управления и структурной схемы системы для ее реализации позволяет по сравнению с серийными регуляторами моцности дуг улучиить динамическую точность стабилизации токов дуг на уровне заданных оптимальных уставок и на основе этого комплексно улучиить показатели энергоэффективности и электромагнитной совместимости режимов дуговой печи и электросети. Библ. 18 , рис. 5. Ключевые слова: дуговая сталеплавильная печь, электрический режим, трехмерный вектор токов фаз, стохастическое управление, дисперсия, оптимизация, адаптация, контур регулирования токов дуг.

Introduction. Arc furnaces are powerful electrical technological installations that belong to a class of complex systems and are characterized by extremely incident, dynamic, nonlinear, phase by phase nonsymmetric nature of loading and continuous action of intense coordinate and parametric disturbances in arc gaps and power supply circuit of three-phase arcs. The specified loading characteristics complicate the control process of such objects and impose appropriate limitations on the system engineering - models, methods and approaches for improving existing systems of control modes and regulation of electric coordinates.

The problem of integrated improvement of energy efficiency and electromagnetic compatibility indices of arc steel-melting furnaces (ASFs) is dictated by the necessity of increasing the competitiveness of electric steels and high alloys on the domestic and foreign markets of metal products. Its state is largely determined by the level of excellence of automatic control systems (ACS) of electrical modes (EM) of arc furnaces, characterized by the speed and dynamic accuracy of coordinate (first of all, arc currents) regulation, the efficiency of electric modes control models, state identification and prediction of the process of electric steelmaking.

It is obvious that for such electrical technological nonlinear stochastic control objects with a range of installed power of power electric equipment of $1 \ldots 175$ MVA, it is most appropriate to use models based on probabilistic characteristics of control processes and that most fully correspond to the nature of the processes which occur in them. Efficiency and completeness of solution of control problems in general and adaptive optimal, in particular, of electrical modes of electric steelmaking are determined, first of all, by the speed and dynamic accuracy of the regulation of the coordinates of the electric mode and, the most important, by currents of arcs.

Problem definition. The complexity of the tasks of the modern theory of adaptive optimal control of stochastic dynamic objects and processes requires the improvement of the mathematical apparatus for their description, identification and control synthesis models, and also requires significant computing power of digital means (microcontrollers, microprocessor devices) for implementation of identification and real-time control.

Unfortunately, the control of modes in the vast majority of arc furnaces is realized on the basis of classical deterministic models of identification of states, parameters, phase by phase regulation of coordinates and control of modes that do not correspond to the stochastic phase by phase interconnected nature of the processes underlying them functioning.
Therefore, in our opinion, the most appropriate approach to solving the above problem is to improve the existing and create new effective methods and approaches for the tasks of controlling modes and coordinate regulation, in particular, the operational formation of control effects based on the three-dimensional vector of phase currents and its probabilistic characteristics.

Review of recent publications. For the first time, the theoretical principles of stochastic models for the formation of control effects for the electromechanical system of displacement of electrodes of three-phase ASFs have been published in [1]. The coefficients of the relationship between the average rectified currents of arcs included in the created model of the ASF are proposed to be determined on the basis of probabilistic analysis and taking into account the correlation interconnections of phase processes in the furnace space of the three-phase arc furnace. The model of electric mode control of the ASF obtained in this work allows to adjust the control signals of typical regulators of the electric mode by current and, thus, to avoid false operations of the regulator of the $i$-th phase (to eliminate false electrodes displacement) by perturbations in adjacent phases. Under this control model, the phase by phase autonomy of electric mode control is improved, which, in turn, increases the efficiency of the electrometallurgical plant. But with the help of such a model, it is impossible to implement the above-stated approach of control of threephase ASF modes.

Similarly, the problems of the phase by phase autonomy of electric mode control by arc furnace phases on the basis of the account of stochastic parameters of perturbations of adjacent phases are considered in the work [2]. According to this work, the signal formed by the displacement of the electrodes in each phase is formed additively from the signals of the dissonance of all three phases, which are normalized by the weight factors. To find the values of these coefficients, the authors obtained a mathematical model that describes the reactions of such a complex object as the ASF on the pre-synthesized control influences and perturbation processes that convert the electric mode of the furnace to a particular state. In the final case, these coefficients are also some averaged over a certain time interval the coefficients of the weight of the signals of discrepancies of phase modes. Nevertheless, it should be noted here that in this paper for the first time it was noted that optimization of the system of controlling the electric mode of the ASF should be carried out with an orientation to such an integral characteristic of the mode as the variance of the three-dimensional vector of arc currents, but specific solutions in this direction in this work are not offered. 
In the paper [3] for the analysis and synthesis of control systems of electric drives, which are under the influence of random perturbations, the expediency of using the probabilistic approach is substantiated. This approach ensures an adequate response of the ACS to the processes and perturbations that take place in the control object. In this paper, the method of formation of the variance of the regulated coordinate, that is, the method of stochastic dynamic stabilization for application in the problems of stabilization of coordinates of electromechanical systems with random perturbations is worked out. In its implementation, it is possible to control the dispersion of the output coordinate of the dynamic system in accordance with the current requirements and conditions of operation of the control object, in particular such as an arc furnace.

In work [4] a mathematical description of the electromechanical control system of electrodes position was worked out, on the basis of which «on-line» synthesis of the desired dynamic characteristics of the state change process on the basis of integral quality criteria is carried out. The proposed approach is based on the account of the phase by phase interconnection of electric modes caused by the peculiarities of the parametric non-symmetric power supply circuit of the three-phase arcs and the impedance or differential law of the formation of a control signal on the displacement of the electrodes. But this work, like the previous one, is far from the idea of applying the control of processes in arc furnaces and the idea of forming a three-dimensional vector of arc currents and its stochastic characteristics.

The mathematical and computer models of control of electrical modes of the three-phase arc furnaces proposed in the papers [5-9] have certain advantages and disadvantages among themselves in terms of the completeness and accuracy of the description of modes, identification of states, conveniences in use and readjustment, but they do not meet the above requirements for energy efficiency and electromagnetic compatibility modes in full, primarily due to the inadequacy of the control models to the nature of the real processes of changing the coordinates of the EM, also because of the high sensitivity of the obtained dynamics to changing parameters of the control object, which is highly undesirable in terms of continuous action of stochastic parametric disturbances in the power circuit of the furnace and in phase arc gaps.

The goal of the work is the development of system and structural solutions for the operative synthesis of the control signal of an arc furnace electric mode on the basis of a three-dimensional vector of arc currents, taking into account the stochastic nature of the processes in the melting space and the power supply circuit of the threephase arcs and has a low sensitivity to the change of the control object parameters, the use of which in comparison with known solutions allows to increase the dynamic accuracy of the stabilization of arc currents at the level specified by the criteria of energy efficiency and electromagnetic compatibility.

The scientific task is to create the method of adaptive optimal control of the electric mode of an arc furnace according to the criterion of the minimum distribution density of a three-dimensional vector of phase currents and the structural scheme of the control system for its realization, which, in comparison with known control methods, enables to increase the dynamic accuracy of the stabilization of arc currents at the given (in particular, optimal) values and thereby improve the energy efficiency and electromagnetic compatibility indicators of arc furnace and power supply network.

Identification of previously unsolved parts of the general problem. The dynamics of the regulation of the EM coordinates of the ASF, in particular the arc currents, in the overwhelming majority of the existing (serial, typical) control systems of the process of electrical steel molding (by using arc power) does not fully meet the high modern requirements for energy efficiency and electromagnetic compatibility indicators of arc furnace modes and power supply network. Therefore, the problem of creating effective system, circuit and algorithmic solutions, which are based on increasing the speed of processes of regulation of phase (arcs) currents and complex improvement on the basis of indicators of energy efficiency and electromagnetic compatibility of modes for today for the electro-metallurgical industry is important and relevant.

Content of research material. In this paper, the term "optimality» is used in the narrow sense, in which the system of automatic control is evaluated only by the indicators of the quality of dynamic processes, and one of the criteria of this quality is the integral quality index the generalized dispersion of the regulated coordinate. Such a description of the quality criteria makes it possible to use modern well-developed mathematical optimization apparatus to find optimal control.

Under the action of the flows of random perturbations and control influences, the electric mode (which is estimated by the stochastic characteristics of arc currents) of a three-phase arc furnace can be in different states.

Define these states by a three-dimensional vector of phase currents, which characterizes the electric mode of the arc furnace during the melting company as:

1 - a state characterized by the given (required) values of the coordinates of the electric mode, in particular by the set values of arc currents;

$\mathbf{2}$ - a state characterized by deviations of arc currents in the domain of admissible directive deviations;

3 - a state characterized by deviations of the arc currents into the region of large, in particular extreme, deviations - short circuits, breaks of arcs and close to them.

It is clear that the concept of being in one or another state is associated with some definite time interval $T_{0}$. The graph of the states of the three-dimensional vector of states of the electric mode of an arc furnace is shown in Fig. 1.

Each of these states is proposed to be identified by means of the integral parameter (indicator) value, which is the generalized variance of the three-dimensional vector of the ASF arc currents. In turn, this integral indicator is defined as the determinant of the matrix of second order moments, or the correlation matrix [10], and it characterizes the value of the deviation of the vector of 
arc currents of the three-phase arc furnace from the desired state.

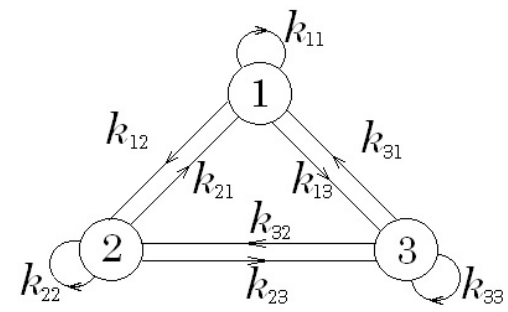

Fig. 1. A graph of states of the electric mode of an arc furnace $k_{1,1}(t), k_{1,2}(t), k_{2,1}(t), k_{2,2}(t), k_{1,3}(t), k_{2,3}(t), k_{3,3}(t), k_{3,1}(t), k_{3,2}(t)-$ the intensities of the transition from state to state

So, having adopted the designation of a threedimensional vector of regulated coordinates (for the considered problem of arc currents) as

$$
\boldsymbol{I}_{a}=\boldsymbol{y}=\left|\begin{array}{lll}
y_{1} & y_{2} & y_{3}
\end{array}\right|,
$$

we obtain an expression for the dispersion of the threedimensional vector in the form:

$$
D_{I_{a}}=D_{y}=\operatorname{det} \boldsymbol{\Lambda}_{y},
$$

where $\Lambda_{y}$ is the correlation matrix, or matrix of moments of the second order of the form:

$$
\boldsymbol{\Lambda}_{y}=\left|\begin{array}{lll}
\lambda_{11} & \lambda_{12} & \lambda_{13} \\
\lambda_{21} & \lambda_{22} & \lambda_{23} \\
\lambda_{31} & \lambda_{32} & \lambda 33
\end{array}\right| .
$$

The criterion for the functioning of such a dynamic system is the desired level of probability of being the system in state 1 during the time of the melting of charge. In view of the above, we write the expression for the density of the three-dimensional vector of the regulated coordinate as:

$$
\begin{aligned}
& p\left(y_{1}, y_{2}, y_{3}\right)=\frac{1}{(2 / \pi)^{3 / 2} \sqrt{\operatorname{det} \Lambda_{y}}} \times \\
& \times \exp \left[-\frac{1}{2} \sum_{i, j=1}^{3} \Lambda_{y_{i, j}}^{-1} \cdot\left|y_{i}-\bar{y}_{i}\right| \cdot\left|y_{j}-\bar{y}_{j}\right|,\right]
\end{aligned}
$$

where $\Lambda_{y_{i, j}}^{-1}=\frac{1}{\operatorname{det} \Lambda_{y}} \cdot A_{i, j}$ are the elements of the inverse matrix $\boldsymbol{\Lambda}_{y}^{-1} ; \boldsymbol{A}_{i, j}$ are the corresponding elements of the attached matrix, and the probability of being of the electric mode of an arc furnace in a given state is found as an integral of density (1):

$$
P\left(y_{1}, y_{2}, y_{3}\right)=\int_{0}^{y_{1}^{*}} \int_{0}^{y_{2}} \int_{0}^{y_{3}^{*}} p\left(y_{1}, y_{2}, y_{3}\right) d y_{1} d y_{2} d y_{3},
$$

where $y_{1}^{*}, y_{2}^{*}, y_{3}^{*}$ are the maximum values of the change of the coordinates of the electric mode, for example, the value of the circuits of the short circuit in the ASF phases.

It is clear that the smaller the variance of the threedimensional vector of the regulated coordinate (the arc currents of the arc furnace), the greater the probability of a state that is identified by such a variance value, i.e., state 1. Taking into account that in a real object we have a flow of disturbances and a flow of control influences that change the state of the system (the state of the electric mode), we write the model of state dynamics in the form of the Kolmogorov-Chapman equation [11]:

$$
\frac{d P_{i}(t)}{d t}=\sum_{j=1}^{3} P_{j, i} \cdot k_{j, i}(t)-\sum_{j=1}^{3} P_{i} \cdot k_{i, j}(t)
$$

and the system of equations for determining the probabilities of individual states is written as:

$$
\begin{aligned}
& \frac{d P_{1}(t)}{d t}=-P_{1}(t) \cdot\left[k_{12}(t)+k_{13}(t)\right]+k_{21}(t) \cdot P_{2}(t)+ \\
& +k_{31}(t) \cdot P_{3}(t) \\
& \frac{d P_{2}(t)}{d t}=-P_{2}(t) \cdot\left[k_{21}(t)+k_{23}(t)\right]+k_{12}(t) \cdot P_{1}(t) \text {; } \\
& \frac{d P_{3}(t)}{d t}=-P_{3}(t) \cdot\left[k_{31}(t)+k_{32}(t)\right]+k_{13}(t) \cdot P_{1}(t) \text {. }
\end{aligned}
$$

From the presented system of equations (2) and graph in Fig. 1 it can be concluded that the intensities of transitions $k_{21}(t) ; k_{31}(t) ; k_{32}(t)$ are formed by controlling effects of the control system, which bring the electric mode of the arc furnace from the unwanted states $\mathbf{2}$ and $\mathbf{3}$, and especially from the state $\mathbf{3}$ to state $\mathbf{1}$. At the same time, the intensities of transitions $k_{12}(t) ; k_{13}(t) ; k_{23}(t)$ are determined by the disturbances that act in the melting space and power circuit of the ASF.

The method of formation of effective control influences was developed in works [12-15], namely, the method of forming a vector of control effects of the socalled second (high-speed electric) circuit of regulating arc currents included in the structure of existing (serial) one-contour electric control systems of electric mode of an arc furnace. The main feature of such a two-contour structure of the electric mode control system of the arc furnace is the high speed of the arc currents regulation (the current regulation time is $0.03-0.04 \mathrm{~s}$ ), which allows to significantly improve the control dynamics, that is, to obtain a high dynamic accuracy of the arc currents stabilization, and thus, with high accuracy to control the dynamics of the state graph, in particular, to transfer the electrical mode of the arc furnace to states $\mathbf{1}$ or $\mathbf{2}$.

The functional scheme of such a two-circuit control system of the EM of the arc furnace is shown in Fig. 2. This system contains the traditional electromechanical (or electrohydraulic) contour for regulating the lengths of the arcs EMCRLA (it is traditionally called the regulator of the arcs power), which has a relatively high inertia, which results in the operation of such a regulator of arcs power is accompanied by a significant dispersion of the coordinates of the EM - lengths, voltages, currents and powers of arcs.

Each phase channel of this circuit includes the arcs voltage sensor (VS) and current sensors (CS), the control signal formation unit (CSFU), the electrode displacement electric drive (EDED) and the electrode displacement mechanism (EDM), and also contains a voltage level switch (VLS) of the furnace transformer FT. Most often, 
in such EMCRLAs, the control signal on the displacement of the electrode in each phase is formed according to the differential law.

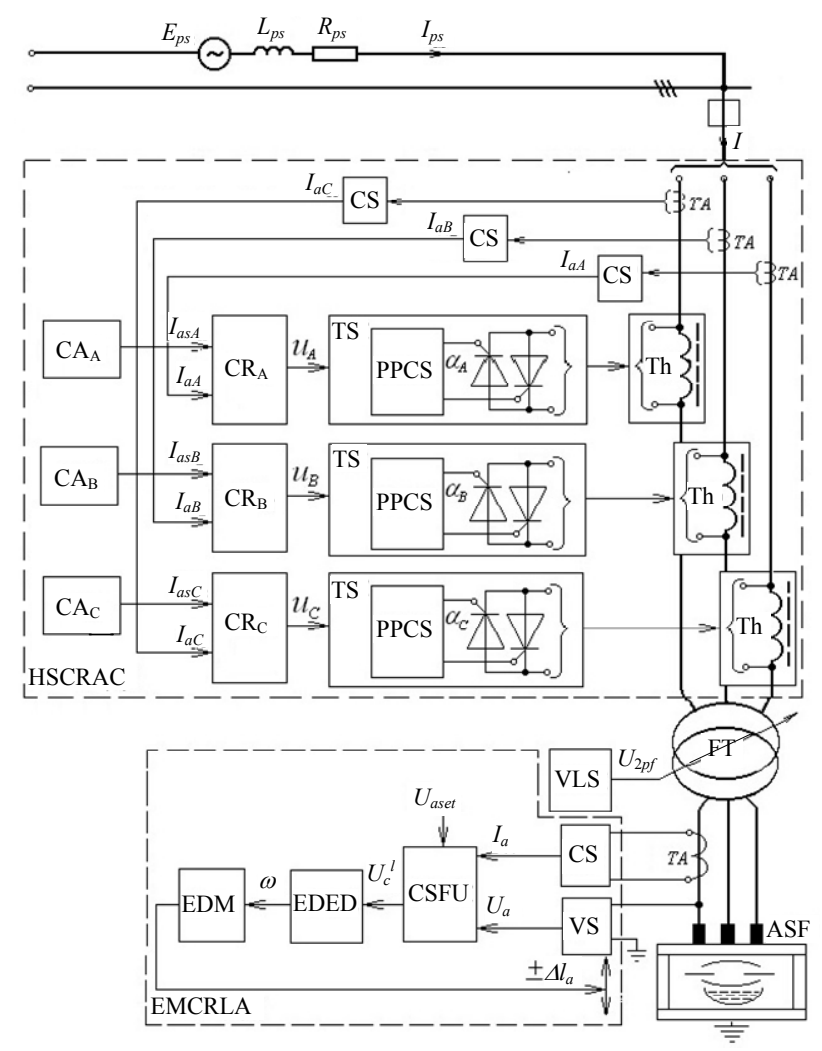

Fig. 2. Functional scheme of the two-circuit control system of the electric mode of the arc furnace

An example of the dynamics of the regulation of arc currents by the electromechanical circuit, performed in the structure of the ACS of the EM of the arc furnace ДСП-200 by the serial regulator of the arcs power of the type АРДМ-Т-12, is illustrated in Fig. 3, $a$ by the fragments of the temporal dependencies of the arcs currents $I_{a j}(t)(j=A, B, C)$ (computer experiments were carried out at time intervals of stationary $T_{c}=180-300 \mathrm{~s}$ of random processes of perturbations by the lengths of arcs of the furnace ДСП-200 for various technological melting stages).

In the composition of each phase channel of the electric high-speed contour for the regulation of arc current (HSCRAC) there are the arc current sensor (CS), adjuster (CA) and the regulator (CR) of the arc current, the thyristor switch (TS), the control effect of which is the time of the shunting of the throttle (Th) on a certain regulated part of the half-period of the voltage given by the angle $\alpha$ of the control of the parallel thyristor-reactor group. At the joint functioning of these two regulating contour, their advantages are combined: reliable ignition of arcs in the treatment of extreme disturbances operational short circuits and breakdowns of the arcs of the EMCRLA and high speed of regulation of arc current of the HSCRAC. As a result of such a combination of contours in the two-contour structure of the ACS of the EM of the ASF it is possible to achieve high controllability and dynamic precision of the stabilization of currents (lengths, voltages, powers) of arcs under the conditions of the action of continuous random transient parametric and coordinate disturbances.
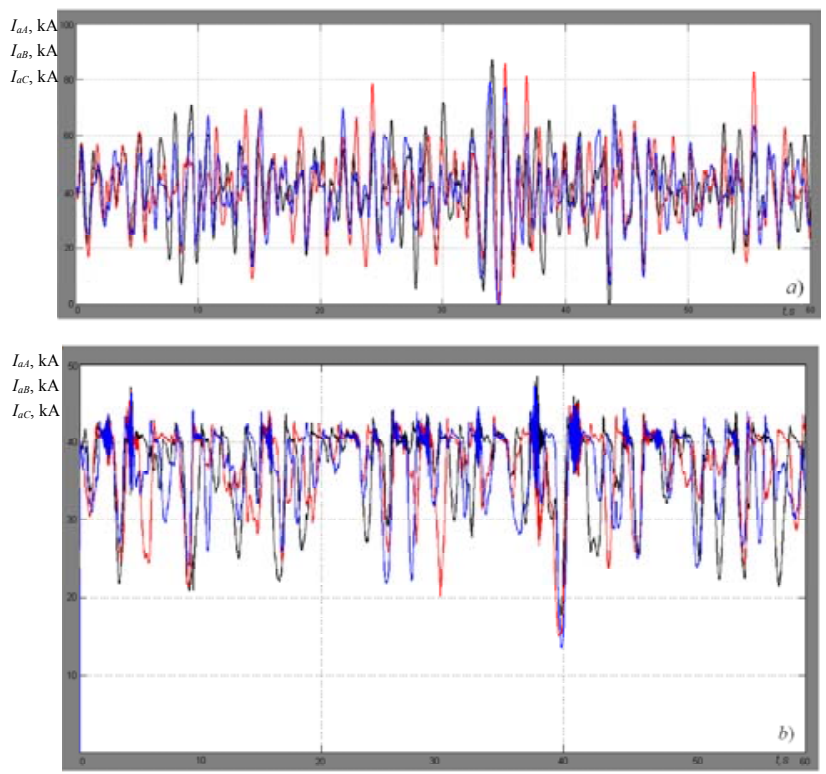

Fig. 3. Temporal dependencies of arc currents of the ДСП-200 furnace at the operation of the regulator АРДМ-Т-12 (a) and АРДМ-Т-12 with a high-speed contour at control by the criterion $D_{Q} \Rightarrow \min (b)$

To compare dynamics, as an example, Fig. 3,b shows the temporal dependencies of arcs currents in the operation of a two-contour system under the influence of random disturbances with the same parameters of stochastic perturbation characteristics using the proportional integral current regulator $\mathrm{CR}$ and $\mathrm{EM}$ optimization based on the scalar criterion for the minimum of the dispersion of the reactive power of the furnace $D_{O} \Rightarrow \mathrm{min}$, which is largely correlated with the criterion for the minimum dispersion of arcs currents. The dispersion of arcs currents in the two-contour structure of the ACS of the EM of the ДСП-200 at the functioning of the proportional-integral regulator was: $D_{I_{a A}}=2.95 \cdot 10^{7} \mathrm{~A}^{2}$; $D_{I_{a_{B}}}=3.15 \cdot 10^{7} \mathrm{~A}^{2} ; D_{I_{a_{C}}}=2.35 \cdot 10^{7} \mathrm{~A}^{2}$. The average on the phases the dispersion of the currents of arcs was $\bar{D}_{I_{a}}=2.82 \cdot 10^{7} \mathrm{~A}^{2}$. The presented temporal dependencies illustrate high speed of regulation and high-quality dynamic stabilization of arcs currents in the structure of the two-contour ACS of the EM of the arc furnace. Comparison of dispersions shown in Fig. 3 for processes of the change of arcs currents $I_{a j}(t)$ with the values of dispersions under other parameters of stochastic disturbances by the arcs lengths shows a considerable (almost an order of magnitude) decrease in the dispersion of arcs currents in the joint operation of electromechanical and high-speed electric contours with a proportional integral regulator of arcs currents in the twocontour structure of the ACS of the EM of the arc furnace in comparison with the operation of a one-contour ACS of the ЕМ (regulator АРДМ-Т-12) [10].

For such a two-contour structure of the ACS of the $\mathrm{EM}$ of the arc furnace, it is important to develop effective 
system-engineering solutions - models of the formation of phase controlling effects of the high-speed contour of regulating the arcs currents of the HSCRAC, which would improve the indicators of the electrical efficiency and electromagnetic compatibility of the arc furnace modes and power grid.

Therefore, it is expedient in the context of the task defined in the work to develop the theoretical bases of a stochastic model of operative synthesis of control influences by a three-dimensional vector of arcs currents in the structure of such a two-contour ACS of the electric mode of the ASF.

For the synthesis of the vector of control effects on the regulation of the arcs currents of the two-contour ACS of the EM of the arc furnace, we apply the principle according to which the optimal change in the distribution density of the three-dimensional arcs currents vector is realized, in particular, in the direction of approximation of this distribution to the form of the $\delta$-function.

So, in the ideal case, the system will better perform its intended purpose, namely, to ensure the state $\mathbf{1}$ of the three-dimensional vector of phases currents, the sooner it will convert the initial distribution density $p\left(y_{A}, y_{B}, y_{C}, t_{0}\right)$ of the three-dimensional vector of currents of arcs of the furnaces in $\delta$-function, or in the $\delta$-distribution, which is combined with the point $y_{A}=y_{A . s e t}, y_{B}=y_{B . s e t}, y_{C}=y_{C . s e t}$, where $y_{A}, y_{B}, y_{C}, y_{A . s e t}, y_{B . s e}, y_{C . s e t}$ are the current and set values of the regulated coordinates - arcs currents of the arc furnace.

This conclusion corresponds to the principle of the statistical theory of transients, according to which, on the basis of the Fokker-Planck-Kolmogorov equation [16], optimal control is obtained in relation to the ctransient of changing the density of the $n$-dimensional probability distribution to the density of the form of the $\delta$-function.

For our case, we write the Fokker-PlanckKolmogorov equation in the form

$$
\frac{d p}{d t}=\sum_{i=1}^{3} \frac{d\left(p \cdot F_{i}\right)}{d y_{i}},
$$

as an equation for a dynamic system in the absence of noise.

In this equation (3) it is indicated: $p$ is the probability distribution density of a three-dimensional vector $p=p\left(y_{1}, y_{2}, y_{3}\right) ; \dot{y}_{i}+F_{i}\left(y_{1}, y_{2}, y_{3}\right)=0$ is the equation describing the system coordinates movement.

For the automatic control system, the functions $F_{i}$ can be represented as a set of two functions:

$$
F_{i}=f_{i}\left(y_{1}, y_{2}, y_{3}\right)-u\left(y_{1}, y_{2}, y_{3}\right),
$$

where the function $f_{i}$ belongs to the control object, and the function $u$-to the control system.

Synthesized in [16] controls for dynamical systems that provide an optimal change in the density of the distribution of the $n$-dimensional vector of regulated coordinates $y_{i}$ are calculated by the expression:

$$
u_{i}=d_{i} \cdot \operatorname{sign}\left(\frac{\partial \ln (p)}{\partial y_{i}}\right),
$$

where $d_{i}$ is the maximum permissible or limit value of control influence; $y_{i}$ is the component of the $n$-dimensional vector of regulated coordinates.
Such a control on one of the coordinates, for example, on the first, for our case, is written as:

$$
u_{1}=d_{1} \cdot \operatorname{sign}\left(\frac{\partial \ln \left(p\left(y_{1}, y_{2}, y_{3}\right)\right)}{\partial y_{1}}\right) \text {. }
$$

To find the appropriate control we write down the distribution density (1) of the three-dimensional vector of the regulated coordinate of the electric mode of the ASF in the form convenient for differentiation:

$$
\begin{aligned}
p\left(y_{1}, y_{2}, y_{3}\right)=\frac{1}{(2 / \pi)^{3 / 2} \sqrt{\operatorname{det} \boldsymbol{\Lambda}_{y}}} \cdot \exp \left[-\frac{1}{2} \cdot \frac{1}{\operatorname{det} \boldsymbol{\Lambda}_{y}} \times\right. \\
\quad \times\left\{A_{11}\left(y_{1}-\bar{y}_{1}\right)^{2}+2 \cdot A_{12}\left(y_{i}-\bar{y}_{1}\right) \cdot\left(y_{2}-\bar{y}_{2}\right)+\right. \\
\left.\quad+2 \cdot A_{13}\left(y_{1}-\bar{y}_{1}\right) \cdot\left(y_{3}-\bar{y}_{3}\right)+A_{22}\left(y_{2}-\bar{y}_{2}\right)^{2}+\right], \\
\left.\left.\quad+2 \cdot A_{32}\left(y_{2}-\bar{y}_{2}\right) \cdot\left(y_{3}-\bar{y}_{3}\right)+A_{33}\left(y_{3}-\bar{y}_{3}\right)^{2}\right\}\right]
\end{aligned}
$$

where $\bar{y}_{1}, \bar{y}_{2}, \bar{y}_{3}$ are the mathematical expectations of phase regulated coordinates, which for the considered object are given by the values of the currents of arcs of individual phases of the ASF.

If we make the necessary mathematical transformations and substitute currents of arcs $I_{a A}, I_{a B}, I_{a C}$ instead of generalized regulated coordinates $y_{i}(i=A, B, C)$, we obtain the expressions for the mentioned control influences $u_{A}, u_{B}, u_{C}$ for each of the phases of the arc furnace in form:

$$
\begin{aligned}
u_{A}=d_{1} & \cdot \operatorname{sign}\left\{\frac { 1 } { \sqrt { \operatorname { d e t } \Lambda _ { I } } } \cdot \left[A_{11}\left(I_{a A}-\bar{I}_{a A}\right)+\right.\right. \\
& \left.\left.+A_{12}\left(I_{a B}-\bar{I}_{a B}\right)+A_{13}\left(I_{a C}-\bar{I}_{a C}\right)\right]\right\} ; \\
u_{B}=d_{2} & \cdot \operatorname{sign}\left\{\frac { 1 } { \sqrt { \operatorname { d e t } \Lambda _ { I } } } \cdot \left[A_{21}\left(I_{a A}-\bar{I}_{a A}\right)+\right.\right. \\
& \left.\left.+A_{22}\left(I_{a B}-\bar{I}_{a B}\right)+A_{23}\left(I_{a C}-\bar{I}_{a C}\right)\right]\right\} ; \\
u_{C}=d_{3} & \cdot \operatorname{sign}\left\{\frac { 1 } { \sqrt { \operatorname { d e t } \Lambda _ { I } } } \cdot \left[A_{31}\left(I_{a A}-\bar{I}_{a A}\right)+\right.\right. \\
& \left.\left.+A_{32}\left(I_{a B}-\bar{I}_{a B}\right)+A_{33}\left(I_{a C}-\bar{I}_{a C}\right)\right]\right\} .
\end{aligned}
$$

As we see, for the operative formation of the control influences $u_{A}(t), u_{B}(t)$, and $u_{C}(t)$ it is necessary to know the matrix $\Lambda_{I}$ of other moments of the three-dimensional vector of the currents of arcs (phases) of the ASF. The operational calculation of control effects by the received model (4) for modern microprocessor devices is a simple (to some extent trivial) technical task.

We note here that the control signals obtained by the equations (4) are formulated as boundary controls and can only be considered as conventionally optimal ones. However, studies [16] show that these controls can be quite close, and even coincide with strictly optimal controls, which translate the $n$-dimensional distribution of the regulated coordinate into $\delta$-function.

The obtained model (4) of operative synthesis of the vector of control signals $u_{A}, u_{B}, u_{C}$ is realized in the proposed structure of the two-contour adaptive control system of arc furnace electric mode, the functional block diagram of which is shown in Fig. 4.

In the presented scheme of the two-contour adaptive ACS by the values of implementations of the average 
rectified currents of the three phases $I_{a A}, I_{a B}, I_{a C}$ of the arc furnace in the block of calculations $\mathrm{BC}$ operatively at each interval of stationary $\left(T_{c}=3-5 \mathrm{~min}\right)$ of the processes of phases currents changes, the calculation of the matrix $\Lambda_{I}$ of other moments of the three-dimensional vector of the currents of arcs of arc furnace, its determinant $\operatorname{det} \boldsymbol{\Lambda}_{I}$ and the values of the elements $\boldsymbol{A}_{i, j}$ of the adjoint matrix $\boldsymbol{A}$ of the inverse matrix $\Lambda_{I}^{-1}$ is performed.

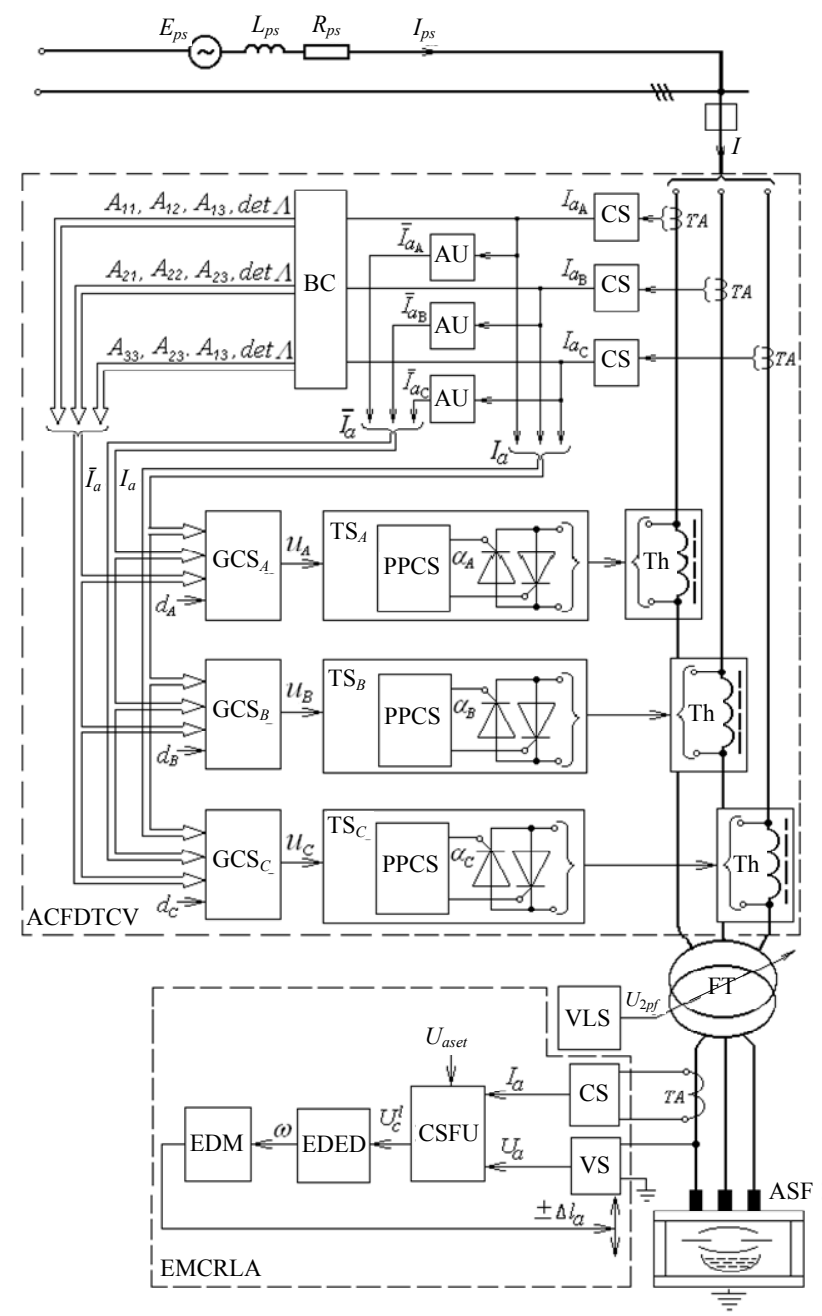

Fig. 4. Functional scheme of the two-contour adaptive control system of arc furnace electric mode for minimization of dispersion of three-dimensional vector of currents

The specified signals from the BC outputs are fed to the third vector input of each phase generator of the control signal for current $I_{a i}$, namely: $A_{11}, A_{12}, A_{13}$, $\operatorname{det} \boldsymbol{\Lambda}_{I}-$ to the third $\mathrm{GCS}_{A}$ input; $A_{21}, A_{22}, A_{23}, \operatorname{det} \boldsymbol{\Lambda}_{I}-$ to the third $\mathrm{GCS}_{B}$ input; $A_{31}, A_{32}, A_{33}, \operatorname{det} \Lambda_{I}-$ to the third $\mathrm{GCS}_{C}$ input, and to the first and second vector inputs of $\mathrm{GCS}_{A}, \mathrm{GCS}_{B}, \mathrm{GCS}_{C}$ the three-dimensional vector of currentaverage rectified values of arcs currents $I_{a i}$ from the outputs of currents censors CS and a threedimensional vector of the averaged on the stationary intervals $T_{c}$ currents $\overline{\boldsymbol{I}}_{a i}$ are input, respectively. The fourth input of the $\mathrm{GCS}_{i}$ is fed by the scalar signal $d$ of the maximum value of the control influence. On the outputs of the $\mathrm{GCS}_{i}$ continuously online phase control signals $u_{i}$ are generated based on the obtained control model (4), which are fed to the corresponding phase thyristor switches $\mathrm{TS}_{i}$. Output signals $\alpha_{i}$ of pulse-phase control systems (PPCSs) determine the moments of shunting/ switching on in the power circuit of the corresponding phase throttles $\mathrm{Th}_{i}$.

The proposed procedure for operative synthesis of control effects $u_{A}(t), u_{B}(t)$, and $u_{C}(t)$ is divided into two parallel processes in time: the first process implements the adaptation of the coefficients of the synthesis model (4) to change the parameters of stochastic characteristics of coordinate and parametric perturbations on the time the interval of melting, and the second one performs online operative with discreteness $\Delta t$ calculation of control effects $u_{A}(t), u_{B}(t)$, and $u_{C}(t)$ in $\mathrm{GCS}_{A}, \mathrm{GCS}_{B}$, and $\mathrm{GCS}_{C}$ units by this model. The first process involves at each interval of stationary $T_{c}$, the duration of which is correlated with the technological stages of melting (the physical and chemical state of the melt) and depends on the types of arc furnaces $\left(\left(T_{c}=180-300 \mathrm{~s}\right)\right.$, the calculation in the $\mathrm{BC}$ of the coefficients of the model (4): $\operatorname{det} \Delta_{I}$, $\bar{I}_{a, j}, A_{n, m}$, and the second one implements the process of calculating the control effects $u_{A}, u_{B}, u_{C}$ and is performed with the interval $\Delta t=0.02 \mathrm{~s}$ in the function of averaging the values (rms) of phases currents $I_{j}\left(t_{k}\right)$ $\left(t_{k}=t_{k-1}+\Delta t, \quad m=1,2,3, \quad n=1,2,3, \quad j=A, B, C\right) \quad$ in this interval.

To verify the effectiveness of the proposed stochastic model for synthesizing the control signals $u_{A}(t)$, $u_{B}(t)$, and $u_{C}(t)$, the corresponding mathematical experiments were performed on the three-phase in instantaneous coordinates Simulink model $[17,18]$ of the two-contour ACS of the ЕМ of the arc furnace ДСП-200 (Fig. 2). The modelling studies were performed at the functioning of the proportional integral arc voltage regulator and using the proposed stochastic model (4) for synthesizing the control signals $u_{A}\left(t_{i}\right), u_{B}\left(t_{i}\right)$, and $u_{C}\left(t_{i}\right)$ which is implemented in the proposed structure of the adaptive ACS of the EM of the arc furnace (Fig. 4), which implements a strategy for minimizing the dispersion of a three-dimensional vector of phases currents.

To do this, a computational block is introduced into the structure of the Simulink model, in which, according to the well-known model [10], on the intervals of stationary $T_{c, i}$, the coefficients of the model (4) $\operatorname{det} \Delta_{I}$, $\bar{I}_{a, j}, \quad A_{n, m}$ are calculated. In the next interval of stationary $T_{c, i+1}$, these coefficients are used in $\mathrm{GCS}_{A}$, $\mathrm{GCS}_{B}$, and $\mathrm{GCS}_{C}$ for synthesis of control signals $u_{A}, u_{B}$, $u_{C}$ by model (4) in the function of current averaged over a period of supply voltage $\Delta t=0.02 \mathrm{~s}$ phase currents $I_{A}$, $I_{B}, I_{C}$. Obtained control $u_{A}, u_{B}, u_{C}$ are applied to the inputs of thyristor switches. At the same time, the new values of the coefficients of the model (4) $\operatorname{det} \Delta_{I}, \bar{I}_{a, j}$, $A_{n, m}$, are used in the next $T_{c, i+2}$ interval of online control signal $u_{A}, u_{B}, u_{C}$, etc. synthesis, are calculated on the current stationary interval $T_{c, i+2}$.

Figure 5 shows the initial fragments of temporal dependencies of phase currents obtained on the Simulink 
model at the control by the above model (4), implementing the strategy of minimizing the dispersion of a three-dimensional vector of phases currents.

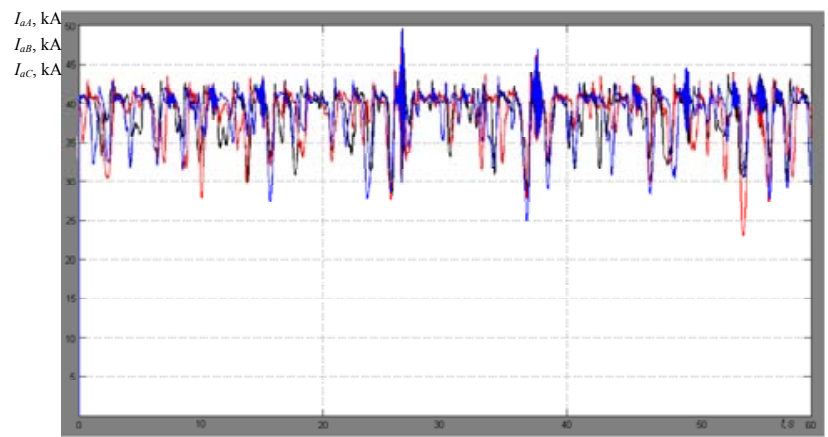

Fig. 5. Temporal dependencies of the arcs currents of the furnace ДСП-200 with the regulation by the obtained model (4) of minimizing the dispersion of the three-dimensional vector of arcs currents in the two-contour structure of the ACS of the EM of the arc furnace ДСП-200

As a result of working out the time dependenceis of the currents of the $\operatorname{arcs} I_{i}(t)$ in Fig. 5 , the following values of their dispersions are obtained: $D_{I_{A}}=0.95 \cdot 10^{7} \mathrm{~A}^{2}$; $D_{I_{B}}=1.05 \cdot 10^{7} \mathrm{~A}^{2} ; D_{I_{C}}=1.03 \cdot 10^{7} \mathrm{~A}^{2}$. The average by the phases the dispersion of the currents of arcs is $\bar{D}_{I}=1.01 \cdot 10^{7} \mathrm{~A}^{2}$.

Comparative analysis of temporal dependencies of arcs currents in Fig. 3, $b$ and Fig. 5 shows that the average by phases dispersion of arcs currents at the regulation by the obtained model (4) of minimizing the dispersion of the three-dimensional vector of arcs current in the two-contour structure of the ACS of the EM decreased by 2.73 times. The computer researches for perturbation processes by the lengths of arcs of other technological melting stages, which differ in frequency spectrum and amplitude of oscillations, have shown that the average dispersion of arcs currents at the regulation by the obtained model (4) of the minimization the dispersion of the three-dimensional arcs current vector in the two-contour structure of the ACS of the EM compared with the use of known proportionalintegral model of the formation of control signals $u_{A}\left(t_{i}\right)$, $u_{B}\left(t_{i}\right)$, and $u_{C}\left(t_{i}\right)$ decreased in 1.6-3 times.

Due to the cyclical updating of the matrix $\Lambda_{I}$ of other moments of the three-dimensional vector of arcs currents of the acr furnace in the block $\mathrm{BC}$ and elements of the vector $I_{a i}$ on the outputs of the averaging units AU, the adaptation of the vector of control influences $u_{A}\left(t_{i}\right), u_{B}\left(t_{i}\right)$, and $u_{C}\left(t_{i}\right)$ to the change of parameters of stochastic characteristics of coordinate and parametric perturbations in the power circuit and arc gaps of the arc furnaces in the full range of melting is realized.

Thus, due to the obtained model (4) of the operative formation and adaptation of the vector of control effects and their realization through the adaptive contour of the formation of the dispersion of the three-dimensional arcs current vector ACFDTCV of the arc furnace one can obtain a significant approximation of the distribution of the three-dimensional vector of arcs phase currents of the arc furnace to the type of the $\delta$-function. And the fact that the reduction of the dispersion of arcs currents significantly influences the improvement of energy efficiency indicators (electrical efficiency coefficient of the furnace, specific energy consumption, specific ASF productivity, the price of the ton of smelted steel, etc.) of an electro-technological installation, which is an $\mathrm{AC}$ arc furnace power is a well-known fact.

It should also be noted that the proposed stochastic model of the regulation of the coordinates of the EM of the arc furnace and the model of adaptive synthesis of control signals based on the three-dimensional vector of phase currents implements a relay, in contrast to the existing control law. Such a law of control of compliance with the conditions of stability, as is known, provides maximum regulation speed and, as a result, high dynamic accuracy of the arc current stabilization at the level of optimal for the selected criterion of values, and also is characterized by a much lower sensitivity to the change of parameters of the control object - the parameters of dynamic volt-ampere characteristics of three-phase arcs and parameters of the elements of the power circuit (short circuit) of an arc furnace. The last feature of the proposed method is particularly important for implementing adaptive optimal control strategies under continuous conditions of intense stochastic parametric perturbations in the power circuit and arc gaps of the furnace during melting.

The stochastic model of operative synthesis and adaptation of the vector of controlling for minimizing the dispersion of the three-dimensional arcs currents vector obtained in the paper is expedient for practical use in the two-contour structures of the ACS of the EM of arc furnaces with a high-speed contour for regulating arc currents.

Conclusions. The developed in the paper the theoretical bases of the method of electric arc furnace control on the basis of the formation of the distribution density of the three-dimensional vector of arc currents make it possible to implement the adaptive optimal control strategy of the electric mode by the criterion of the minimum dispersion of arc currents. As the results of the performed model researches show, the synthesis of the vector of control of arc currents by the obtained stochastic model (4) compared with the use of the proportional-integral regulator of arc current for controlling the EM reduces the dispersion of arc currents by 1.6-3 times. The minimization of the arc current dispersion positively affects the reduction of the power of electrical losses in the elements of the short arc furnace network and, as a result, reduces the specific energy consumption, the corresponding increase in the furnace productivity and the electric efficiency of the arc furnace. In addition, the transformation of the threedimensional vector of arc currents into the $\delta$-function in the control of the electric mode greatly reduces the consumption of reactive power of the furnace and, accordingly, increases the power factor, reduces the volatility and deviation of the network voltage on the power supply buses of the furnace and accordingly reduces the dose of the flicker.

\section{REFERENCES}

1. Lozinskyi O.Yu., Maruschak Y.Yu. Three-dimensional stochastic model of the electric mode regulation of an arc 
furnace. Industrial Process Automation in Engineering and Instrumentation, 1993, no.31, pp. 7-11. (Ukr).

2. Lozinsky O.Yu., Parancuk Ya.S., Lozinsky A.O. Optimization of dynamic regimes of interconnected electromechanical systems. Bulletin of Lviv Polytechnic National University, «Electric Power and Electromechanical Systems» series, 2001, no.421, pp. 98-103. (Ukr).

3. Lozynskyi O.Yu., Parancuk Ya.S., Moroz V.I. Synthesis of the control process for electromechanical systems that are under the influence of random perturbations. Bulletin of NTU «KhPI». Series: Problems of automated electric drive. Theory and practice, 1994, pp. 104-106. (Ukr).

4. Lozinsky O.Yu., Parancuk Ya.S., Tsyapa V.B. Mathematical description of the dynamics of the regulation of the position of the electrodes of the chipboard model in the space of states. Bulletin of Lviv Polytechnic National University, "Electric Power and Electromechanical Systems» series, 2017, no.840, pp. 54-60. (Ukr).

5. Nikolaev A., Povelitsa E., Kornilov G., Anufriev A. Research and Development of Automatic Control System for Electric Arc Furnace Electrode Positioning. Applied Mechanics and Materials, 2015, vol.785, pp. 707-713. doi: 10.4028/www.scientific.net/amm.785.707.

6. Ghiormez L., Panoiu M. Current control of a 3-phase electric arc furnace using fuzzy logic. ANNALS of Faculty Engineering Hunedoara - International Journal of Engineering, 2015, Fascicule 4 Tome XIII, pp. 237-242.

7. Nikolaev A.A., Tulupov P.G. Method of setting optimum asymmetric mode of operation of electric arc furnace. 2016 11th France-Japan \& 9th Europe-Asia Congress on Mechatronics (MECATRONICS) / 17th International Conference on Research and Education in Mechatronics (REM), Jun. 2016. doi: 10.1109/mecatronics.2016.7547111.

8. Zheng T., Makram E.B. An adaptive arc furnace model. IEEE Transactions on Power Delivery, 2000, vol.15, no.3, pp. 931-939. doi: 10.1109/61.871355.

9. Hooshmand R., Banejad M., Torabian Esfahani M. A New Time Domain Model for Electric Arc Furnace. Journal of Electrical Engineering, 2008, vol.59, no.4, pp. 195-202.

10. Pugachov V.S. Teoriia sluchainykh funktsii i ee primenenie $k$ zadacham avtomaticheskogo upravleniia [The theory of random functions and its application to problems of automatic control]. Moscow, Fizmatizdat Publ., 1960. 883 p. (Rus).

11. Kazakov V.A. Vvedenie $v$ teoriiu markovskikh protsessov $i$ nekotorye radiotekhnicheskie zadachi [Introduction to the theory of Markov's processes and some radio engineering problems]. Moscow, Soviet radio Publ., 1973. 232 p. (Rus).
12. Lozynskyy O., Lozynskyy A., Paranchuk Y., Paranchuk R., Marushchak Y., Malyar A. Analysis and Synthesis of Intelligent System for Electric Mode Control in Electric Arc Furnace. Part of the Lecture Notes in Electrical Engineering book series (vol.452). Analysis and Simulation of Electrical and Computer Systems, 2017, pp. 111-130. doi: 10.1007/978-3-319-63949-9_7.

13. Lozynskyi O., Lozynskyi A., Paranchuk Y., Paranchuk R., Holovach I., Tsyapa V. Fuzzy extreme control and electric mode coordinates stabilization of arc steel-melting furnace. 2016 XIth International Scientific and Technical Conference Computer Sciences and Information Technologies (CSIT), Sep. 2016. doi: 10.1109/stc-csit.2016.7589866.

14. Lozynskyy O., Paranchuk Y., Paranchuk R. Fuzzy control law of electrode travel in arc steelmaking furnace. 16th International Conference on Computational Problems of Electrical Engineering (CPEE), Sep. 2015. doi: 10.1109/cpee.2015.7333349.

15. Lozinskyy O.Yu., Paranchuk Y.S. Optimization of the modes of the process control system for electric steel-melting in arc steel-smelting furnaces. Electrical engineering, 2004, no.6, pp. 50-54. (Rus).

16. Krasovskyi A.A. Statisticheskaia teoriia perekhodnykh protsessov $v$ sistemakh upravleniia [Statistical theory of transient processes in control systems]. Moscow, Nauka Publ., 1968. 240 p. (Rus).

17. Lozynskyi O.Y., Paranchuk Y.S., Paranchuk R.Y., Matico F.D. Development of methods and means of computer simulation for studying arc furnace electric modes. Electrical engineering \& electromechanics, 2018, no.3, pp. 28-36. doi: 10.20998/2074-272X.2018.3.04.

18. Lozynskyy O., Paranchuk Y., Stakhiv P. The Study of Dynamics of the Two-Loop Arc Furnace Electric Mode ACS on a Simulink-model. Przeglad Elektrotechniczny, 2018, vol.1, no.12, pp. 24-27. doi: 10.15199/48.2018.12.06.

Received 30.04.2019

O.Y. Lozynskyi ${ }^{1}$, Doctor of Technical Science, Professor,

A.O. Lozynskyi ${ }^{1}$, Doctor of Technical Science, Professor,

Y.S. Paranchuk ${ }^{1}$, Doctor of Technical Science, Professor,

R.Y. Paranchuk ${ }^{1}$, Candidate of Technical Science,

${ }^{1}$ Lviv Polytechnic National University,

12, S. Bandera Str., Lviv, 79013, Ukraine,

e-mail: yparanchuk@yachoo.com

\section{How to cite this article:}

Lozynskyi O.Y., Lozynskyi A.O., Paranchuk Y.S., Paranchuk R.Y. Synthesis and analysis of arc furnace electrical mode control system on the basis of three-dimensional phase currents vector distribution. Electrical engineering \& electromechanics, 2019, no.4, pp. 26-34. doi: 10.20998/2074-272X.2019.4.04. 